\author{
PAWEŁ WIĄZEK \\ ORCID: 0000-0002-9153-4539 \\ Uniwersytet Wrocławski \\ Instytut Historii Państwa i Prawa \\ Zakład Powszechnej Historii Państwa i Prawa
}

\title{
MIT I PARADYGMAT RACJONALNEGO PRAWODAWCY W ŚWIETLE WYBRANYCH PRZYKŁADÓW ORZECZNICTWA ORAZ LEGISLACJI SEJMU VIII KADENCJI
}

\begin{abstract}
Abstrakt: Autor podjął próbę refleksji nad występowaniem paradygmatu racjonalnego prawodawcy w teorii i praktyce stosowania prawa we współczesnej Polsce. Wskazując na endemiczny charakter problemu badawczego w polskim prawoznawstwie, dążył on do skonfrontowania stanowiska doktryny z orzecznictwem sądowym ostatnich lat oraz praktyką legislacyjną Sejmu VIII kadencji. Wszechstronne ujęcie zagadnienia motywowane było chęcią sformułowania hipotez i wniosków mogących inspirować kolejnych eksploratorów podjętej problematyki. Podsumowując wyniki przeprowadzonych badań, autor przedstawił swoje krytyczne stanowisko, uznając, że koncepcja racjonalnego prawodawcy budzi istotne wątpliwości i uzasadnione zastrzeżenia, co powoduje, że wymaga ona reinterpretacji.
\end{abstract}

Słowa kluczowe: teoria prawa, prawoznawstwo, filozofia prawa, legislacja, orzecznictwo sądowe

\section{IDEA RACJONALNEGO LEGISLATORA W DYSKURSIE TEORETYCZNOPRAWNYM}

Prawo będące najwyższym osiągnięciem jest podstawą ludzkiej godności i wolności oraz warunkiem demokratycznej formy sprawowania władzy ${ }^{1}$. Jego rola we współczesnym świecie jest niepodważalna².

${ }^{1}$ L.L. Fuller, Anatomia prawa, Lublin 1968, s. 9.

2 M.A. Liwo, Nieracjonalność działań prawodawcy jako jedna z przyczyn niepoprawności prawa - wybrane przykłady z prawa administracyjnego, karnego i prawa pracy, „Przegląd Prawa Publicznego" 2019, nr 6, s. 10. 
Postulat racjonalnego zachowania człowieka jest dla naszej kultury oczywisty. Dążenie do racjonalności to jeden z najdawniejszych i najbardziej fundamentalnych celów, od wieków stawianych sobie przez człowieka ${ }^{3}$.

Wspólną dyrektywą metodologiczną wielu nauk humanistycznych jest dyrektywa apriorycznie zakładająca racjonalność ludzkiego zachowania z punktu widzenia podejmującego działanie podmiotu ${ }^{4}$. Przyjmuje się nawet, że to właśnie założenie jest wyznacznikiem wyróżniającym nauki humanistyczne ${ }^{5}$. Problem racjonalności i jej kryteriów jest zagadnieniem uwikłanym w spory z rozmaitych poziomów rozważań filozoficznych. Jak nietrudno zauważyć, sam termin „racjonalność" nasuwa pewne trudności interpretacyjne. Wiążą się one z faktem, że istnieje wiele płaszczyzn, na których termin może być stosowany ${ }^{6}$. Na potrzeby prowadzonych wywodów wystarczająca będzie konstatacja uznająca zachowanie ludzkie za racjonalne wówczas, gdy jest działaniem celowym, w którym środki do założonego celu dobierane są na podstawie wiedzy o powiązaniach między rzeczywistymi zjawiskami i przy przyjęciu określonych kryteriów wyboru?

Celowe do dalszych dociekań wydaje się rozważenie szerokiego ujęcia procesu tworzenia prawa, to jest jako zespołu uporządkowanych, następujących po sobie czynności, obejmujących podjęcie przez określony podmiot pewnego zamysłu dokonania zmian w życiu społecznym ${ }^{8}$, następnie przygotowanie $\mathrm{w}$ tym celu projektu aktu prawotwórczego i podjęcie formalnoprawnych kroków, prowadzących do ustanowienia nowych norm prawnych, wreszcie in fine - jego publikację 9 . Być może dla projekcji możliwie pełnego obrazu problemowego stanu rzeczy warto byłoby również zwrócić uwagę na zjawisko podejmowania prac legislacyjnych niezwieńczonych finalnie ustanowieniem nowych norm prawnych. Godne uwagi byłyby zwłaszcza te przypadki, gdy ustawodawca, powziąwszy zamiar ustanowienia nowych regulacji prawnych, ostatecznie zamysłu tego nie realizuje, rezygnując z pierwotnej idei wobec uznania, że regulacje takie nie byłyby w konkretnym przypadku i okolicznościach celowe ${ }^{10}$. Ten aspekt zdaje się

${ }^{3}$ Z. Drozdowicz, O typach i typologizacji racjonalizmu. Kilka uwag wstepnych, [w:] Z. Drozdowicz, Z. Melosik, S. Sztajer, O racjonalności $w$ nauce $i$ w życiu społecznym, Poznań 2009, s. 9.

4 Por. np. P. Oleś, Do dyskusji dla czasopisma „Diametros”, „Diametros” 2006, nr 7, s. 155.

5 J. Kmita, Z metodologicznych problemów interpretacji humanistycznej, Warszawa 1971, s. $27 \mathrm{n}$.

${ }^{6}$ R. Kleszcz, Kryteria racjonalności, „Filozofia Nauki” 4, 1996, nr 2 (14), s. 121.

7 Por. E. Kustra, Racjonalny ustawodawca analiza teoretycznoprawna, Torun 1980, s. 113. Zob. także Z. Ziembiński, Metodologiczne zagadnienia prawoznawstwa, Warszawa 1974, s. 116.

$8 \mathrm{~W}$ takim ujęciu proces prawotwórczy rozpoczynałby się od ustalenia przez pewien podmiot, że w pewnej dziedzinie życia społecznego należy osiągnąć określone stany rzeczy (cele); por. S. Wronkowska, Zagadnienia racjonalnego tworzenia prawa, „Studia Prawnicze” 1979, z. 2 (60), s. 6 .

9 Ibidem, s. 5.

10 Odstąpienie od pierwotnego pomysłu legislacyjnego nastąpić może jeszcze przed formalnym wystąpieniem z inicjatywą ustawodawczą. 
niebagatelnym dla próby ustosunkowania się zarówno do paradygmatu racjonalnego ustawodawcy, jak i prawodawcy rzeczywistego (w kontekście jego kondycji legislacyjnej) i wreszcie ewentualnej, wzajemnej ich konfrontacji. Idea racjonalności prawodawcy, w szczególności wynikająca z obiektywnej wiedzy naukowej stojącej za legislatorem, uznawana jest za kontynuację dziedzictwa Oświecenia, a jej sednem miała być wiara w możliwość mądrego, roztropnego i sprawiedliwego stanowienia prawa ${ }^{11}$. „Racjonalny prawodawca” może być „prawodawcą doskonałym", jeśli opiera się na najlepszej i dostępnej w danym okresie wiedzy oraz na ocenach uznawanych za najsłuszniejsze ${ }^{12}$. Stosując metodę formalnodogmatyczną, ukształtowano koncepcję idealnego ustawodawcy, wywodzoną z pozytywizmu prawniczego ${ }^{13}$. Różnica między obydwoma pojęciami sprowadza się do tego, iż idea prawodawcy doskonałego oprócz założeń związanych z formalnie rozumianą racjonalnością obejmuje też założenia merytoryczne, dotyczące między innymi treści przypisywanych prawodawcy przekonań i ocen ${ }^{14}$. W pracach innych autorów pojęcie racjonalności prawodawcy obejmuje zarówno aspekty formalne, jak i materialne (treściowe) ${ }^{15}$. Rozwój nauk prawnych w ciągu lat umacniał pierwotną ideę, czyniąc stopniowo racjonalność normodawcy założeniem leżącym u fundamentów dogmatyki prawniczej, obecnym zarówno w sferze teorii i filozofii prawa, jak i w praktyce jego stosowania. Z punktu widzenia teorii poznania naukowego przyjęcie takiego założenia można zinterpretować jako zastosowanie paradygmatu badawczego w prawoznawstwie ${ }^{16}$. Poszczególne własności założenia racjonalnego legislatora wpisują się w większość cech paradygmatu naukowego, ich zaś ciągłe użycie w stanowieniu, stosowaniu i egzegezie tekstów prawa prowadzi do efektów przewidzianych w klasycznych koncepcjach paradygmatu ${ }^{17}$.

W nauce reprezentowany jest pogląd uznający, że postulat racjonalnego prawodawcy (racjonalności prawodawstwa) jest powszechnie uznanym założeniem

11 T. Chauvin, T. Stawecki, P. Winczorek, Wstep do prawoznawstwa, Warszawa 2017, s. 208.

12 S. Wronkowska, Z. Ziembiński, Zarys teorii prawa, Poznań 1997, s. 163. Więcej na temat prawodawcy doskonałego (racjonalność II stopnia) zob. Ziembiński, Wstęp do aksjologii dla prawników, Warszawa 1990, s. 162-176.

13 Por. G.K. Walkowski, Koncepcja idealnego ustawodawcy, [w:] idem, Teoria państwa i prawa, http://www.teoria-panstwa-i-prawa.com/koncepcja.html (dostęp: 5.02.2020).

14 A. Borowicz, Argument interpretacyjny odwohujacy się do woli rzeczywistego prawodawcy, „Studia Prawno-Ekonomiczne” 79, 2009, s. 11.

15 Por. np. S. Wronkowska, Prawodawca racjonalny jako wzór dla prawodawcy faktycznego, [w:] Szkice z teorii prawa i szczegółowych nauk prawnych, red. S. Wronkowska, M. Zieliński, Poznań 1989, s. 122-124.

$16 \mathrm{Na}$ temat pojęcia paradygmatu zob. np. K. Jodkowski, Paradygmat, [w:] Filozofia a nauka. Zarys encyklopedyczny, red. Z. Cackowski, Wrocław 1987, s. 456; A. Podsiad, Stownik terminów i pojęć filozoficznych, Warszawa 2000, s. 611. Więcej na ten temat zob. zwłaszcza T.S. Kuhn, Struktura rewolucji naukowych, Warszawa 2009, s. 85 n.

17 P. Kantor-Kozdrowicki, Racjonalność prawodawcy jako paradygmat nauk prawnych, „Folia Iuridica Universitatis Wratislaviensis” 7, 2018, nr 1, s. 95-96. 
stojącym u podstaw teorii i praktyki prawoznawstwa ${ }^{18}$. Nie w pełni koresponduje on jednak z opinią wielu uznanych luminarzy teorii prawa, mniej lub bardziej stanowczo eksponujących endemiczny charakter omawianej koncepcji.

Istotnie, trudno podważyć tezę, że domniemanie racjonalnego prawodawcy jest specyfiką polskiej kultury prawnej ${ }^{19}$, co nota bene często jest jednym z podstawowych zarzutów ze strony krytyków tej idei ${ }^{20}$. Na gruncie prawa europejskiego założenie racjonalnego ustawodawcy nie jest elementem dyskursu interpretacyjnego ${ }^{21}$. W innych kulturach prawnych idea racjonalności prawodawcy nie odgrywa aż tak ważnej roli w dyskursie interpretacyjnym. Znacznie większe znaczenie przypisuje się natomiast argumentom odwołującym się w toku wykładni prawa do zamiarów i przekonań rzeczywistego legislatora, przy czym za podstawowe źródło ustaleń w tej kwestii przyjmuje się oficjalne dokumenty towarzyszące procesowi ustawodawczemu na jego kolejnych etapach (travaux preparatoires) $)^{22}$.

Amerykańska doktryna prawna wyróżnia trzy podstawowe typy normatywnych teorii wykładni23 ${ }^{23}$. Szczególnie reprezentatywna wydaje się zwłaszcza koncepcja „,intencjonalistyczna”, postulująca dążenie do interpretowania prawa w sposób zgodny z zamierzeniami i przekonaniami uczestników procesu legislacyjnego ${ }^{24}$. Za podstawowe źródło ustaleń co do treści tych zamierzeń i przekonań przyjmuje się materiały dokumentujące przebieg procesu stanowienia prawa (legislative histo$r y)^{25}$. Sądy w systemach prawa anglosaskiego (amerykańskiego lub brytyjskiego) powołują się czasami na domniemanie racjonalności prawodawcy, niemniej jedynie przy założeniu, że domniemanie takie ma charakter wzruszalny ${ }^{26}$.

Podobne stanowisko zajmuje niemiecka teoria prawa, akcentująca wśród podstawowych argumentów interpretacyjnych przesłankę odwołującą się do woli hi-

18 L. Pszczółkowski, Racjonalne prawodawstwo, [w:] Wielka encyklopedia prawa, t. 7, red. B. Hołyst, R. Hauser, Warszawa 2014, s. 365.

19 Por. M. Zirk-Sadowski, Instytucjonalny i kulturowy wymiar integracji prawnej, [w:] Zmiany społeczne a zmiany w prawie. Aksjologia, konstytucja, integracja europejska, red. L. Leszczyński, Lublin 1999, s. 41; zob. także T. Grzybowski, Racjonalny prawodawca a orzecznictwo sądowe, https://www.academia.edu/5151143/Racjonalny_prawodawca_a_orzecznictwo_s\%C4\%85dowe (dostęp: 1.02.2020). Skrócona wersja została opublikowana w dodatku do „Gazety Prawnej (Prawnik)” 9.01.2013.

20 Tak np. L. Morawski, Teoria prawodawcy racjonalnego a postmodernizm, „Państwo i Prawo" 2000, z. 11 (657), s. 1, 36-37.

21 M. Zirk-Sadowski, Prawo a uczestniczenie w kulturze, Łódź 1998, s. 91-92.

22 A. Borowicz, op. cit., s. 10-11.

23 Teorie „tekstualistyczne” (textualist theories), teorie ,intencjonalistyczne” (intentionalist theories) oraz teorie „dynamiczne” (dynamic theories); W. Eskridge, P. Frickey, E. Garrett, Legislation and Statutory Interpretation, New York 2000, s. 211-247.

${ }^{24}$ Ibidem, s. 214.

25 A. Borowicz, op. cit., s. 11.

26 Interpreting Statutes, A Comparative Study, red. D.N. MacCormick, R. Summers, Dartmouth 1991, s. 391; por. T. Morawski, Teoria prawodawcy..., s. 31. 
storycznego prawodawcy ${ }^{27}$ jako jednego z trzech podstawowych celów wykładni prawa - oprócz dążenia do ustalenia językowego znaczenia tekstu prawnego oraz do zapewnienia materialnej racjonalności norm prawnych ${ }^{28}$.

W polskiej doktrynie teoretycznoprawnej idea racjonalnego prawodawcy w swoim modelowym ujęciu pojawiła się w latach siedemdziesiątych ubiegłego stulecia, rozwijając się głównie za sprawą publikacji L. Nowaka ${ }^{29}$ i wkrótce, podzielającego jego tezy, J. Wróblewskiego ${ }^{30}$. Zgodnie z tą koncepcją konieczną przesłanką wykładni prawa jest zasada racjonalności, właściwa wszelkiej interpretacji humanistycznej, w tym prawniczej ${ }^{31}$. Odwołuje się ona do wielu kontrfaktycznych i idealizacyjnych założeń co do wiedzy i preferencji prawodawcy, pozwalających prawnikowi właściwie zinterpretować tekst prawny mimo jego wad, wynikających chociażby z nieusuwalnej „otwartej tekstowości” wyrażeń języka naturalnego ${ }^{32}$, w którym tekst ten został sformułowany. Teoria racjonalnego prawodawcy pomyślana została jako narzędzie optymalizacji tekstów prawnych ${ }^{33}$, mające umożliwiać prawnikom takie ich odczytywanie, by decyzje stosowania prawa można było racjonalnie uzasadnić, nawet jeżeli w rzeczywistości teksty te nie są wolne od wad. W tym kontekście tworzy ona odpowiedź na roszczenie racjonalności decyzji stosowania prawa, które zakorzenione jest w naszej kulturze prawnej tak mocno, że podnoszone jest do rangi zasady systemowej, dającej się zrekonstruować z wielu przepisów obowiązującego prawa ${ }^{34}$.

Koncepcja racjonalnego prawodawcy pozwoliła stworzyć model racjonalnego tworzenia prawa oparty na jej założeniach teoretycznych. Ma on charakter normatywny w tym sensie, że wskazuje, co powinien uwzględniać legislator, jeżeli ma być prawodawcą racjonalnym. Stanowi on wskazania, jak ustawodawca powinien tworzyć prawo. Do podstawowych elementów tego modelu zaliczono: założenie celu określonego w stopniu dostatecznie sprecyzowanym w kwestii wyboru środków służących jego realizacji; ustalenie prawidłowości określających powiązanie między typem stanów rzeczy, do których należy cel, a typem zjawisk prowadzących do zaistnienia tych pierwszych (potencjalne środki do celu);

27 R. Alexy określa tego rodzaju argument jako ein genetisches Argument; idem, Theorie der juristischen Argumentation, Frankfurt am Main 1983, s. 291-294.

28 H-J. Koch, H. Rüssmann, Jurstische Begründungslehre, München 1982, s. 184.

${ }^{29}$ L. Nowak, Interpretacja prawnicza. Studium z metodologii prawoznawstwa, Warszawa 1973, s. 218.

30 J. Wróblewski, Teoria racjonalnego tworzenia prawa, Wrocław 1985, s. 343.

31 L. Nowak, op. cit., s. 42; zob. także J. Kmita, L. Nowak, O racjonalizujacym charakterze badań humanistycznych, „Studia Filozoficzne” 1969, nr 5, s. 58.

32 F. Waismann, Verifiability, [w:] Logic and Language, Series I, red. A. Flew, Oxford 1953, s. $119 \mathrm{n}$

${ }^{33}$ L. Nowak, op. cit., s. 174.

34 Por. M. Król, Zasada racjonalnej decyzji stosowania prawa, „Studia Prawno-Ekonomiczne” 22, 1979; B. Wojciechowski, Dyskrecjonalność sędziowska, Toruń 2004, s. 277 n.; zob. zwłaszcza T. Grzybowski, op. cit., s. 1. 
ustalenie, jakie ze środków do założonego celu mogą być środkami prawnymi jego realizacji; wybór określonego środka prawnego do realizacji założonego celu i wreszcie - ustanowienie określonych przepisów obowiązującego prawa ${ }^{35}$.

Praktyczna realizacja teoretycznego modelu racjonalnego tworzenia prawa wymaga spełnienia przyjętych a priori założeń aksjologicznych, mogących budzić mniej lub bardziej uzasadnione wątpliwości i skłaniać do polemiki.

Racjonalność językowa prawodawcy opiera się na uznaniu, że prawodawca doskonale zna język, w którym formułuje przepisy prawne. Problem jednak pojawia się w związku z fikcją rodzimego języka (native speaker), który bezbłędnie posługuje się danym językiem naturalnym. W wypadku języka tekstów prawnych koncepcja taka nastręcza istotnych trudności. Do języka prawnego zalicza się bowiem jakieś wyrażenia po prostu dlatego, że użyto ich w tekście normatywnym, a nie ze względu na odrębny system reguł znaczeniowych takiego języka ${ }^{36}$.

Racjonalność epistemologiczna prawodawcy opiera się na uznaniu, że ustawodawca ma należytą wiedzę społeczną i wiedzę o związkach przyczynowych między wskazywanymi przezeń działaniami a ich skutkami, w związku z czym stanowi tylko normy zwiększające prawdopodobieństwo podejmowania przez adresatów norm działania prowadzącego do spowodowania określonych pożądanych stanów rzeczy.

Wreszcie racjonalność prakseologiczna zakłada, że prawodawca w swej działalności nie popełnia błędów prakseologicznych, a więc nie ustala norm tautologicznych, kontrtautologicznych czy też między sobą niezgodnych, sprzecznych, przeciwnych prakseologicznie ${ }^{37}$.

$\mathrm{Na}$ gruncie omawianej koncepcji strukturę powierzchniową tej dyscypliny wiedzy tworzą akty rozumowań prawniczych zmierzające do rozwiązania problemów walidacyjnych i interpretacyjnych. Teoria racjonalnej legislacji uzasadnia stosowane przez prawników reguły rozumowania, a te zaś z kolei uzasadniają poszczególne akty rozumowań walidacyjnych i interpretacyjnych, przy czym o ile reguły rozumowań są niekiedy przez prawników formułowane wprost, o tyle założenia składające się na teorię racjonalnego ustawodawcy występują jedynie jako zakładany przez prawników element uzasadnienia owych reguł ${ }^{38}$. Idea racjonalnego legislatora umożliwia zatem wyjaśnienie rozumowań prawniczych w wyniku rekonstrukcji ich głębokiej struktury — przez opis założeń przyjmowanych (choć nieartykułowanych wyraźnie) przez autorów tychże rozumowań. Zasadniczą część koncepcji racjonalnego prawodawcy tworzy opis właściwości przypisywa-

35 W. Lang, J. Wróblewski, S. Zawadzki, Teoria państwa i prawa, Warszawa 1979, s. $377-$ 378.

${ }^{36}$ Więcej T. Gizbert-Stadnicki, Is an empirical theory of the language of law possible?, [w:] Polish Contributions to the Theory and Philosophy of Law, red. Z. Ziembiński, Amsterdam 1987, s. 113.

37 Z. Ziembiński, Wstęp do aksjologii..., s. 163-164.

38 L. Nowak, op. cit., s. 51. 
nych przez prawników racjonalnemu prawodawcy (właściwości przypisywanych jego wiedzy i preferencjom $)^{39}$.

Koncepcja racjonalnego legislatora jest żywo dyskutowana, a w ciągu ostatnich dziesięcioleci zaprezentowano pełne spektrum jej interpretacji ${ }^{40}$ oraz stanowisk zarówno jej przychylnych, jak i wielce krytycznych ${ }^{41}$. Temperatura sporu uczestników teoretycznoprawnego dyskursu interpretacyjnego bywa zaskakująco wysoka, co obrazują opinie niepozbawione kwiecistej retoryki. Wśród apologetów koncepcji można znaleźć i takich, którzy uznają, że prawnik chcący zrezygnować z koncepcji racjonalnego prawodawcy zachowuje się jak człowiek, który twierdzi, że wystarczy wykreślić prawo ciążenia z podręczników fizyki, a możliwe stanie się latanie ${ }^{42}$. Tonacja ta nieobca jest sceptykom czy zdeklarowanym wprost krytykom idei racjonalnego legislatora, czego przykładem wypowiedź zawierająca przewrotne pytanie: czy założenie racjonalności prawodawcy obowiązuje też przy interpretacji wytworów ludzi ciężko chorych psychicznie, zwykłych idiotów czy skrajnych fanatyków? ${ }^{43}$

Nauka prawa w Polsce przeszła kolejno przez etapy budowania założeń teoretycznych koncepcji racjonalnego prawodawcy ${ }^{44}$, zastosowania ich w praktyce (dziedzictwo szkoły poznańskiej) ${ }^{45}$ oraz krytycznej analizy ${ }^{46}$.

\section{DOMNIEMANIE RACJONALIZMU PRAWODAWCY W ORZECZNICTWIE SĄDOWYM}

By móc pełniej ocenić znaczenie i rolę, jaką paradygmat ten odgrywa w realnie funkcjonującym systemie prawnym, konieczne jest skonfrontowanie teorii z praktyką, czyli dogmatyki z judykaturą. Już pobieżny przegląd orzecznictwa zdaje się wskazywać, że pogłoski o rychłej śmierci idei racjonalnego prawodawcy

39 A. Borowicz, op. cit., s. 12.

40 Zob. np. M. Zirk-Sadowski, Konstrukcja racjonalnego prawodawcy a kompetencja komunikacyjna, [w:] Szkice z teorii prawa i szczegółowych nauk prawnych, red. S. Wronkowska, M. Zieliński, Poznań 1990.

41 T. Grzybowski, op. cit., s. 1.

42 A. Kozak, Charakterystyka kategorii „,racjonalny prawodawca” w sadowym stosowaniu prawa, [w:] Filozoficzno-teoretyczne problemy sądowego stosowania prawa, red. M. Zirk-Sadowski, Łódź 1997, s. 134.

43 L. Morawski, Teoria prawodawcy..., s. 36.

44 Zob. np. L. Nowak, op. cit., s. 219; J. Wróblewski, op. cit., s. 343.

45 Zob. np. S. Wronkowska, Problemy racjonalnego tworzenia prawa, Poznań 1982, s. 243; eadem, Zagadnienia racjonalnego..., s. 3-39; M. Zieliński, Wyktadnia prawa. Zasady - regulywskazówki, Warszawa 2002, s. 333.

46 Zob. np. L. Morawski, Zasady wykładni prawa, Torun 2006, s. 303; idem, Wstęp do prawoznawstwa, Toruń 1996, s. 251; S. Wojtczak, Wplyw konceptu „racjonalnego prawodawcy” na polska kulture prawna, [w:] Wielowymiarowość prawa, red. J. Czapska, M. Dudek, M. Stępień, Toruń 2014, s. 88 n.; J. Czaja, O nieracjonalności pojęcia ,, racjonalnego ustawodawcy”, [w:] Studia z filozofii prawa, red. J. Stelmach, Kraków 2001, s. 175-185. 
okazują się zdecydowanie przedwczesne. Do podobnej konkluzji skłaniają wyniki dokonanej online kwerendy orzecznictwa sądowego, z której wynika, że frazę „racjonalny prawodawca” zawiera kilka tysięcy uzasadnień orzeczeń zamieszczonych w zdigitalizowanych bazach danych ${ }^{47}$.

To, że judykatura tak często odnosi się do mocno ugruntowanej w doktrynie koncepcji, nie oznacza jeszcze, czy w przyjętej linii orzecznictwa ideę tę respektuje, odrzuca, czy skłania się ku jakiemuś stanowisku pośredniemu. Odpowiedzi wymaga też pytanie, w jakim stopniu orzecznictwo jest w tej kwestii konsekwentne.

Bezsprzecznie odrzucić należy tezę o zdecydowanym bojkotowaniu tej reguły interpretacyjnej.

W uchwale składu siedmiu sędziów z 2001 roku SN w odniesieniu do stanowiska prokuratora, który w motywach swojego wniosku odwoływał się głównie do woli ustawodawcy, wyraził pogląd, że

ustawodawca, którego „wola” podlega uwzględnieniu w procesie wykładni, to nie ustawodawca realny, faktyczny - który nie może krępować dozwolonej swobody interpretacyjnej sądu, bo związek takiego ustawodawcy z przepisem prawa został z chwilą jego uchwalenia (wejścia w życie) zerwany — lecz tzw. ustawodawca racjonalny, wykreowany. „Wolę ustawodawcy” należy zatem odczytywać wyłącznie na podstawie tekstu stanowionego prawa, starając się ją racjonalizować i obiektywizować, między innymi przez odniesienie do celów (funkcji) instytucji prawnych w całokształcie materiału normatywnego ${ }^{48}$.

Analogiczne stanowisko zaprezentował NSA w orzeczeniu z 2011 roku odnośnie do skargi kasacyjnej Dyrektora Izby Skarbowej od wyroku WSA, uznając za zbyt daleko idącą interpretację sądu pierwszej instancji, zgodnie z którą termin zwrotu może rozpocząć swój bieg, zanim jeszcze została wyrażona w sposób prawem przewidziany jego kwota. NSA uznał mianowicie, że wykładnia ta jest nie do pogodzenia z przyjmowanym w interpretacji prawniczej założeniem o racjonalności prawodawcy, stanowiącym istotne kryterium determinacji znaczeń wyrażeń języka prawnego, w tym przypadku zwrotu „od dnia złożenia rozliczenia przez podatnika"49.

Do tego nurtu zaliczyć należy stanowisko NSA przyjęte w uzasadnieniu do wyroku z 1994 roku dotyczącym skargi na decyzje organów podatkowych, w którym uznał, że

47 Wyniki na podstawie kwerendy dokonanej na podstawie danych zamieszczonych w Centralnej Bazie Orzeczeń Sądów Administracyjnych (3382 uzasadnienia), http://orzeczenia.nsa.gov.pl/cbo/ query (dostęp: 13.02.2020), w systemie Lex Prestige (310 uzasadnień) oraz w bazie LexPolonica Perfecta Online, https://borg.wolterskluwer.pl/Auth/FormAuthPage.ashx?applicationId=SelfService \&referer $=$ https $\% 3 \mathrm{~A} \% 2 \mathrm{~F} \% 2 \mathrm{Fborg}$. wolterskluwer.pl\%2FProducts\%2FIndex.ashx (dostęp: 13.02.2020), (330 uzasadnień) według stanu na dzień 12 stycznia 2012; T. Grzybowski, op. cit., s. 2.

48 Uchwała SN z dnia 17 stycznia 2001 roku, III CZP 49/00, OSNC 2001, nr 4, poz. 53.

49 Wyrok NSA z dnia 20 grudnia 2011 roku, IFSK 481/11, z aprobującą glosą T. Grzybowskiego, OSP 2012, z. 5. 
z założenia językowej racjonalności prawodawcy wyprowadza się w doktrynie prawniczej50 i w praktyce stosowania prawa ogólniejszą regułę, iż jeżeli przepis jednoznacznie w danym języku formułuje normę postępowania, to tak właśnie należy dany przepis rozumieć. Z założenia językowej racjonalności ,prawodawcy” wyprowadzić też można regułę interpretacyjną [...], że każde słowo użyte w tekście prawnym jest potrzebne dla zrekonstruowania podatkowej normy postępowania: nie można natomiast przyjmować za prawidłową takiej wykładni, która uznawałaby jakieś sformułowania tekstu za zbędne ${ }^{51}$.

W judykaturze można dostrzec jednak i inną linię, reprezentującą więcej dystansu wobec doktrynalnego aksjomatu.

W uchwale składu siedmiu sędziów Sądu Najwyższego z 2006 roku dotyczącej podstawy wymiaru emerytury ubezpieczonego, który wcześniej miał ustalone prawo do renty z tytułu niezdolności do pracy, wyrażono pogląd kwestionujący walor subsydiarności wykładni historycznej ${ }^{52}$. SN uznał, że „,przy rozstrzyganiu wątpliwości nie jest pomocna wykładnia historyczna, ponieważ omówione wcześniej zmiany przepisów, jakie następowały przed wejściem w życie ustawy o emeryturach i rentach, nie dają się odczytać jako konsekwentne stanowisko ustawodawcy w omawianej kwestii" ${ }^{53}$.

Jeszcze dosadniej swoje wątpliwości wobec doktrynalnego dogmatu wyraził NSA w uchwale z 2007 roku, dotyczącej skargi kasacyjnej od wyroku wojewódzkiego sądu administracyjnego „w przedmiocie odmowy stwierdzenia nadpłaty w podatku dochodowym od osób fizycznych". Wyrażając w niej swoją wątpliwość wobec ,zastosowania w tej sprawie reguł wykładni funkcjonalnej i historycznej”, stwierdził wprost, że

ze względu na charakter unormowania obejmującego zwolnienie podatkowe [...], nadmierną częstotliwość zmian [...], sądy administracyjne [...] nie powinny doszukiwać się intencji i zamiarów ustawodawcy, który wskutek braku precyzji przy stanowieniu [...] przepisów podatkowych tworzy prawo, któremu daleko do doskonałości, rodzące poważne wątpliwości interpretacyjne, a jako takie nie może być wykładane na niekorzyść podatników ${ }^{54}$.

W tym samym duchu utrzymana jest konkluzja wyrażona w wyroku NSA z 2009 roku uznająca, że „możliwa jest krytyczna analiza zarówno czynności prawodawcy faktycznie stanowiącego akty prawne, jak i samych aktów prawnych"55. Expressis verbis kwestionuje ona aksjomatyczny charakter koncepcji racjonalnego legislatora, konfrontując go z faktycznym ustawodawcą ${ }^{56}$.

50 W wyroku odesłanie do: A. Redelbach, S. Wronkowska, Z. Ziembiński, op. cit., s. 203 n.

51 Wyrok NSA z dnia 8 czerwca 1994 roku, SA/Po 692/94, M. Podat. 1995, nr 5, s. 151.

52 Wykładnia historyczna nawiązuje do koncepcji racjonalnego prawodawcy, opierając się na założeniu, że każdej zmianie tekstu prawnego przyświecały określone motywy, z których podstawowym jest zmiana prawa; por. B. Brzeziński, Podstawy wyktadni prawa podatkowego, Gdańsk 2008, s. 99.

53 Uchwała SN z dnia 20 lipca 2006 roku, II UZP 9/06, OSNP 2007, nr 1-2, poz. 21.

54 Uchwała NSA z dnia 18 czerwca 2007 roku, II FPS 4/06, ONSAiWSA 2007, nr 5, poz. 114.

55 Wyrok NSA z dnia 20 sierpnia 2009 roku, II FSK 504/08, LEX nr 513043.

56 Por. T. Grzybowski, op. cit., s. 3. 
Trybunał Konstytucyjny w wyroku z 1996 roku w sprawie odmowy ustalenia powszechnie obowiązującej wykładni art. 4 ust 1 pkt 10 ustawy z dnia 21 marca 1985 roku o drogach publicznych uznał, że „wątpliwości językowych nie da się rozstrzygnąć na gruncie wykładni funkcjonalnej. Pozostałe przepisy ustawy nie dają bowiem podstaw do sformułowania jakiejś ogólnej dyrektywy celowościowej” oraz: „wątpliwości językowych nie da się usunąć w oparciu o wykładnię funkcjonalną, brak bowiem ku temu dostatecznych podstaw ustawowych" 57 .

Trudno także uznać za bezkrytyczne wobec koncepcji racjonalnego prawodawcy stanowisko, jakie zajął SN w wyroku z 1998 roku w sprawie z powództwa Skarbu o uzgodnienie treści księgi wieczystej, w którym wyraził on pogląd, że choć

przy thumaczeniu znaczenia normy należy jej przypisać takie znaczenie, jakie ma ona w języku potocznym [...] - [to jednak jeżeli] — ważne względy przemawiają za odstępstwem od tego znaczenia, wolno odstąpić od znaczenia literalnego (potocznego) danego przepisu, gdy znaczenie to pozostaje w oczywistym konflikcie lub sprzeczności ze znaczeniem innych norm systemu, gdy prowadzi do absurdalnych z punktu widzenia społecznego lub ekonomicznego konsekwencji, gdy prowadzi do rażąco niesprawiedliwych rozstrzygnięć lub pozostaje w oczywistej sprzeczności $\mathrm{z}$ powszechnie akceptowanymi normami moralnymi ${ }^{58}$.

Nawet stosunkowo pobieżny przegląd orzecznictwa nie pozostawia wątpliwości co do daleko idącej niekonsekwencji i ewidentnego braku jednolitej linii orzeczniczej w kwestii stosunku do domniemania racjonalności prawodawcy. Rozbieżność stanowisk judykatury jest w tym wypadku odpowiedzią na szerokie spektrum poglądów reprezentowanych w doktrynie. Ryzykowne byłby twierdzenie że teoria racjonalnego legislatora przeżywa w orzecznictwie niewątpliwy regres, stając się reliktem minionej epoki. Równie błędne byłoby twierdzenie o jej pozadyskusyjnej, absolutyzowanej akceptacji i traktowaniu w kategoriach aksjomatu. Trafną wydaje się wyważona opinia, uznająca postrzeganie teorii racjonalnego legislatora jako wzruszalnego domniemania, podlegającego relatywizacji, gdy podejście ortodoksyjne staje się absurdalne. Polskie ius interpretandi ma więc charakter kompromisowy.

\section{RACJONALNOŚĆ DZIAŁALNOŚCI PRAWOTWÓRCZEJ WSPÓŁCZESNEJ LEGISLACJI}

Skoro prawo w życiu każdej ludzkiej społeczności ma gwarantować sprawiedliwość, bezpieczeństwo i pomyślność wspólnoty i tworzących ją jednostek, to zagadnienie jego racjonalnego charakteru oraz rzetelności procesu prawotwórczego i odpowiedzialności legislatorów jest kwestią o fundamentalnym znaczeniu. $\mathrm{O}$ ile rolą jurysprudencji i judykatury jest zapewnienie najoptymalniejszych warunków procesu prawotwórczego, o tyle zadaniem legislacji jest ich umiejętne wykorzy-

57 Postanowienie z dnia 26 marca 1996 roku, sygn. akt W. 12/95, https://www.saos.org.pl/ judgments/205729 (dostęp: 3.05.2020).

58 Wyrok SN z dnia 8 maja 1998 roku, OSNC 1999, nr 1, poz. 7. 
stanie i zrealizowanie stawianych przed nią zadań w zakresie kreowania obowiązującego prawa. $Z$ pewnością warto monitorować i wnikliwie eksplorować proces prawotwórczy, by móc go właściwie ocenić i doskonalić. Tymczasem już pobieżne spojrzenie na radosną twórczość legislacyjną sejmów poprzedniej i obecnej kadencji budzić może uzasadniony niepokój. Krytycyzm wobec poczynań prawodawcy, będących ewidentnym zaprzeczeniem racjonalnego postępowania, staje się bowiem powszechny, a argumenty kontestatorów — trudne do podważenia.

Modelowym przykładem postępowania legislatora wbrew doktrynalnym założeniom koncepcji racjonalnego prawodawcy są dzieje nowelizacji ustawy o IPN z 18 grudnia 1998 roku $^{59}$. W styczniu 2018 roku Sejm uchwalił jej nowelę, w której wprowadzono postanowienia:

Art. 55a. 1. Kto publicznie i wbrew faktom przypisuje Narodowi Polskiemu lub Państwu Polskiemu odpowiedzialność lub współodpowiedzialność za popełnione przez III Rzeszę Niemiecką zbrodnie nazistowskie [...] lub za inne przestępstwa stanowiące zbrodnie przeciwko pokojowi, ludzkości lub zbrodnie wojenne lub w inny sposób rażąco pomniejsza odpowiedzialność rzeczywistych sprawców tych zbrodni, podlega grzywnie lub karze pozbawienia wolności do lat $3^{60}$.

Zaledwie kilka miesięcy później, 26 czerwca, Sejm uchwalił kolejną nowelę ustawy o IPN, w której zamieszczono przepis w brzmieniu: ,art. 1, p.2. [...] uchyla się art. 55a"61. Referujący projekt szef Kancelarii Prezesa Rady Ministrów Michał Dworczyk perorował z mównicy sejmowej: „odpowiedzialność karna nigdy nie była dla nas celem samym w sobie. Miała być tylko instrumentem do walki o prawdę historyczną. Dziś należy stwierdzić, że jej skuteczna ochrona jest możliwa także za pomocą innych środków i działań. [...] Narzędzia cywilnoprawne, [...] mogą być skuteczniejsze niż ścieżka karno-prawna"62. Rzeczniczka rządu Joanna Kopcińska w radiowej „Trójce” podkreśliła, że: „to, co zostaje po odrzuceniu przepisów karnych, wystarcza, aby skutecznie walczyć z nieprawdą i skutecznie ukarać tych, którzy będą zakłamywali prawdę historyczną" "63. W uzasadnieniu do projektu nowelizacji wnioskodawca wskazał, że analiza stanowiska prezydenta (skierował styczniową nowelizację w trybie kontroli następczej do Trybunału

59 Ustawa z dnia 18 grudnia 1998 roku o Instytucie Pamięci Narodowej — Komisji Ścigania Zbrodni przeciwko Narodowi Polskiemu, Dz.U. z 1998 r. Nr 155, poz. 1016.

${ }^{60}$ Ustawa z dnia 26 stycznia 2018 roku o zmianie ustawy o Instytucie Pamięci Narodowej — Komisji Ścigania Zbrodni przeciwko Narodowi Polskiemu, ustawy o grobach i cmentarzach wojennych, ustawy o muzeach oraz ustawy o odpowiedzialności podmiotów zbiorowych za czyny zabronione pod groźbą kary, Dz.U. z 2018 r. poz. 369.

61 Ustawa z dnia 27 czerwca 2018 roku o zmianie ustawy o Instytucie Pamięci NarodowejKomisji Ścigania Zbrodni przeciwko Narodowi Polskiemu oraz ustawy o odpowiedzialności podmiotów zbiorowych za czyny zabronione pod groźbą kary, Dz.U. z 2018 r. poz. 1277.

${ }^{62} \mathrm{https} / / / \mathrm{tvn} 24 . p \mathrm{pl}$ polska/nowelizacja-ustawy-o-ipn-przeglosowana-ra849046-2581011 (dostęp: 12.02.2020).

63 Ibidem. W wątpliwy sposób koresponduje to z założeniami doktryny, uznającej, że „Cechą działań racjonalnego prawodawcy jest posiadanie pełnych danych (wiedzy) co do związków między alternatywnymi działaniami i ich skutkami”, zob. E. Kustra, op. cit., s. 126. 
Konstytucyjnego) i prokuratora generalnego Zbigniewa Ziobry oraz przebiegu debaty publicznej, która toczyła się wokół przedmiotowej nowelizacji, prowadzi do wniosku, że bardziej efektywnym sposobem ochrony dobrego imienia Rzeczypospolitej Polskiej i Narodu Polskiego, biorąc pod uwagę cel ustawy, będzie wykorzystanie narzędzi cywilnoprawnych ${ }^{64}$.

Fundamentem paradygmatu racjonalnego prawodawcy jest założenie o jasno sprecyzowanych celach legislacji, których osiągnięcie zapewnia doskonała wiedza ustawodawcy o skutkach procedowanych zmian prawnych. Przykładem tego, jak dalece stanowisko doktryny nie znajduje potwierdzenia $w$ realiach podejmowanych przedsięwzięć ustawodawczych, jest uchwalenie ustawy z dnia 11 lutego 2016 roku o pomocy państwa w wychowywaniu dzieci65. Zgodnie z przyjętą ustawą expressis verbis celem świadczenia wychowawczego jest częściowe pokrycie wydatków związanych z wychowywaniem dziecka, w tym z opieką nad nim i zaspokojeniem jego potrzeb życiowych (art. 4). W świetle deklarowanego celu, jakim jest walka z ubóstwem, należy zadać pytanie o skuteczność i sprawiedliwość społeczną proponowanego mechanizmu. Wątpliwości budzić może już sama diagnoza co do pauperyzacji. Jeśli przyjmiemy ostatnią dekadę za punkt odniesienia, widzimy, że spadły wszystkie trzy wskaźniki ubóstwa: ubóstwo ustawowe, ubóstwo relatywne i ubóstwo skrajne ${ }^{66}$. Tymczasem okazało się, że wkrótce po wprowadzeniu ustawy wszystkie wzrosły ${ }^{67}$, co potęguje dyskredytację racjonalności prawodawcy (ocena rzeczywistych następstw przyjętych rozwiązań prawnych) ${ }^{68}$.

${ }^{64} \mathrm{Z}$ pewnością założenia normatywnego wymogu regulacji prawnej, w myśl którego racjonalny prawodawca wydaje wyłącznie przepisy, które powinny być spełniane w określanych przez prawo nie warunkach, pozostawiają w tym kontekście bardzo wiele do życzenia; zob. E. Kustra, op. cit., s. 120; por. W. Lang, L. Morawski, T. Gabrysiak, Koncepcja „prawodawcy doskonatego” i jej zastosowanie w prawoznawstwie, PiP 1976, z. 1-2, s. 132-133.

65 Ustawa z dnia 11 lutego 2016 roku o pomocy państwa w wychowywaniu dzieci, Dz.U. z 2016 r. poz. 195.

66 Przyjmując za punkt odniesienia dane dostępne w momencie tworzenia dokumentu — czyli porównanie roku 2013 z 2014 — dostrzec można stabilizację ubóstwa skrajnego $(7,4 \%)$, stabilizację bóstwa relatywnego (16,2\%) i spadek ubóstwa ustawowego z 12,8\% do 12,2\%; A. Gromada, Czemu stuży program rodzina 500 plus? Analiza celów polityki publicznej i polityki partyjnej, „Ruch Prawniczy, Ekonomiczny i Socjologiczny" 80, 2018, z. 3, s. 232, 233.

$67 \mathrm{https}$ ://konkret24.tvn24.pl/polska,108/pis-chwali-sie-zmniejszeniem-skrajnego-ubostwa-dane-gus-pokazuja-ze-w-2018-r-wzroslo,963938.html, https://stat.gov.pl/obszary-tematyczne/ warunki-zycia/ubostwo-pomoc-spoleczna/zasieg-ubostwa-ekonomicznego-w-polsce-w-2018roku,14,6.html (dostęp: 13.02.2020).

68 W 2018 roku odnotowano zahamowanie tendencji spadkowej zasięgu ubóstwa ekonomicznego szacowanego na podstawie wydatków gospodarstw domowych. W porównaniu z 2017 roku wzrósł zasięg ubóstwa skrajnego (z mniej więcej 4\% osób do blisko 5\% osób) oraz relatywnego (z około 13\% osób do mniej więcej 14\% osób). Wzrost ubóstwa dotyczył w większym stopniu mieszkańców wsi niż miast. Znacząco zwiększyło się ubóstwo wśród gospodarstw domowych utrzymujących się głównie ze świadczeń społecznych (innych niż emerytury i renty). Odnotowano także wzrost zasięgu ubóstwa wśród gospodarstw domowych z dziećmi; GUS, Zasięg ubóstwa ekono- 
Ocena skutków realizacji (OSR) z 2015 roku wymienia dwa zasadnicze cele projektu, to jest pomoc dla rodzin wychowujących dzieci oraz przeciwdziałanie spadkowi demograficznemu w Polsce, przez przyznanie tym rodzinom nowego świadczenia wychowawczego ${ }^{69}$.

Już w pierwszym zdaniu projektu pojawia się problem z identyfikacją celu: nie wiadomo, czym jest spadek demograficzny. Możemy jedynie zakładać, że projektodawcy chodzi o ujemny przyrost naturalny lub spadek współczynnika dzietności ${ }^{70}$. Tymczasem raport GUS wywołuje poważne wątpliwości co do efektywności rozwiązań legislacyjnych w kwestii pożądanych zmian demograficznych, świadcząc o ujemnej stopie przyrostu rzeczywistego ${ }^{71}$.

In fine pozostaje problem oceny wzajemnej korelacji podstawowych celów regulacji prawnej. W całym uzasadnieniu ustawy nie znajdziemy jednak ani jednego zdania na poparcie tezy, że pieniądze zachęcają do większej dzietności ${ }^{72}$. Konkludując, należy stwierdzić, że nie przedstawiono diagnozy uzasadniającej, że przez planowaną politykę cel zostanie osiągnięty, tym samym nie można zaliczyć programu 500+ do polityki opartej na faktach. Uzasadnienie nie analizuje dotychczasowych rozwiązań w obszarze interwencji ani nie zastanawia się nad lukami (ciągłość polityki), ani też nie zapewnia synchronizacji programu z dotychczasowymi narzędziami (komplementarność) ${ }^{73}$.

Krytyczna analiza przepisów obowiązujących de lege lata, prowadzona w ramach podejmowanej problematyki badawczej, należy do istotnych zadań współ-

micznego w Polsce w 2018 r., https://stat.gov.pl/obszary-tematyczne/warunki-zycia/ubostwo-pomoc-spoleczna/zasieg-ubostwa-ekonomicznego-w-polsce-w-2018-roku,14,6.html.

69 OSR z 2 grudnia 2015 roku, https://n-16-5.dcs.redcdn.pl/file/o2/tvn/web-content/m/p121/f/ c88d8d0a6097754525e02c2246d8d27f/39a5afaf-ac9f-49e5-9a37-5903131dd4a0.pdf. Więcej na ten temat zob. A. Gromada, Rodzina 500+ jako polityka publiczna, Warszawa 2017. Zob. także https://gk24.pl/koniec-500-plus-w-2021-500-zostanie-zlikwidowane-program-nie-daje-wynikow-13022020/ar/c3-14770806. Por. też uzasadnienie ustawy z dnia 11 lutego 2016 roku o pomocy państwa w wychowywaniu dzieci: https://legislacja.rcl.gov.pl/docs//2/12279566/12326797/123267 98/dokument202543.pdf.

70 Precyzja koncepcyjna jest kluczowa w polskiej sytuacji, w której wskaźniki te przez ostatnie lata oddziaływały w przeciwnych kierunkach: od lat sześćdziesiątych spadek współczynnika dzietności (TRF) zanotowano aż 35 razy, podczas gdy przyrost naturalny, dzięki szybko rosnącej długości życia, był dodatni przez cały ten czas z wyjątkiem lat 2005 i 2013-2015; A. Gromada, Czemu stuży program...

${ }^{71}$ W końcu 2018 roku liczba ludności Polski wyniosła 38411 tys., to jest o 22,4 tys. mniej niż w końcu 2017 roku. Tym samym także stopa przyrostu rzeczywistego była ujemna i wyniosła $-0,06 \%$. Oznacza to, że na każde 10 tys. ludności ubyło 6 osób, natomiast w 2017 roku odnotowano nieznaczny przyrost rzeczywisty — na każde 100 tys. ludności przybyła 1 osoba $(-0,001 \%)$; GUS, Sytuacja demograficzna Polski do 2018 roku. Tworzenie i rozpad rodzin, Warszawa 2019, s. 15, https://stat.gov.pl/obszary-tematyczne/ludnosc/ludnosc/sytuacja-demograficzna-polski-do-2018-roku-tworzenie-i-rozpad-rodzin,33,2.html (dostęp: 13.02.2020).

72 A. Gromada, Czemu stuży program..., s. 236.

73 Ibidem. 
czesnego prawoznawstwa ${ }^{74}$. Znaczenie prowadzonych eksploracji determinuje ich pragmatyzm i użyteczność - formułowane na podstawie ich wyników postulaty de lege ferenda wskazywać bowiem mogą na wadliwość obowiązujących przepisów prawa: formalną (sprzeczności, luki) lub merytoryczną (niezgodność z systemem akceptowanych ocen).

Przeprowadzone badania skłaniają do uzasadnionej konkluzji o potrzebie uchylenia bądź co najmniej ponownego rozpatrzenia idealistycznych założeń doktryny prawniczej w kontekście paradygmatu racjonalnego prawodawcy. Dotyczy to zwłaszcza fundamentalnego założenia doktrynalnego materialnej niesprzeczności systemu prawa ${ }^{75}$, jak również z założeń normatywnego wymogu efektywności regulacji prawnej, w myśl którego prawodawca racjonalny wydaje wyłącznie przepisy, które powinny być spełniane w określanych przez prawo warunkach ${ }^{76}$.

W ostatnich latach powstają także regulacje prawne, których treść wskazuje na inne jeszcze groźne zjawisko - prymat polityki nad prawem, w celu wprowadzenia określonych jego zmian. Powoduje to w konsekwencji stanowienie prawa w sposób nieracjonalny, ale odpowiadający racjom większości parlamentarnej, w wyniku czego prawo w jego hierarchii i treści prowadzi do wypaczeń i ograniczeń ${ }^{77}$. Problem potęguje jakość sceny politycznej i brak fachowego zaplecza w kwestii działań politycznych i legislacyjnych podejmowanych przez partie polityczne i polityków.

Należy mieć nadzieję, że niezbędna, pogłębiona refleksja nad stanowieniem prawa umożliwi uniknięcie wielu rozwiązań prawnych, których racjonalność budzi poważne wątpliwości i uzasadnione zastrzeżenia ${ }^{78}$.

\section{THE MYTH AND PARADIGM OF THE RATIONAL LEGISLATOR IN THE CONTEXT OF SELECTED EXAMPLES OF JURISPRUDENCE AND LEGISLATION OF THE POLISH SEJM OF THE 8TH TERM}

Summary

The author of the publication reflected on the existence of the rational legislator's paradigm in the theory and practice of applying law in contemporary Poland. Noting the endemic nature of the research problem in Polish jurisprudence, the author tried to confront the position of the doctrine with the judicial decisions of recent years and the legislative practice of the Sejm of the 8th term. The comprehensive approach to the issue was motivated by striving to formulate hypotheses and conclusions that could inspire subsequent explorers of the issues raised. Summing up the results of the conducted research, the author presented his critical position, recognising that the concept

\footnotetext{
74 E. Kustra, op. cit., s. 119.

75 Zob. W. Lang, L. Morawski, T. Gabrysiak, op. cit., s. 132-133.

76 Ibidem.

77 M.A. Liwo, op. cit., s. 17.

78 Ibidem, s. 18.
} 
of a rational legislator raises serious doubts and justified objections, which means that it requires reinterpretation.

Keywords: theory of law, jurisprudence, philosophy of law, legislation, judicial decisions

\section{BIBLIOGRAFIA}

Alexy R., Theorie der juristischen Argumentation, Frankfurt am Main 1983.

Borowicz A., Argument interpretacyjny odwolujący się do woli rzeczywistego prawodawcy, „Studia Prawno-Ekonomiczne" 79, 2009.

Brzeziński B., Podstawy wykładni prawa podatkowego, Gdańsk 2008.

Chauvin T., Stawecki T., Winczorek P., Wstęp do prawoznawstwa, Warszawa 2017.

Czaja J., O nieracjonalności pojęcia „racjonalnego ustawodawcy”, [w:] Studia z filozofii prawa, red. J. Stelmach, Kraków 2001.

Drozdowicz Z., O typach i typologizacji racjonalizmu. Kilka uwag wstepnych, [w:] Z. Drozdowicz, Z. Melosik, S. Sztajer, O racjonalności w nauce i w życiu społecznym, Poznań 2009.

Eskridge W., Frickey P., Garrett E., Legislation and Statutory Interpretation, New York 2000.

Fuller L.L., Anatomia prawa, Lublin 1968.

Gizbert-Stadnicki T., Is an empirical theory of the language of law possible?, [w:] Polish Contributions to the Theory and Philosophy of Law, red. Z. Ziembiński, Amsterdam 1987.

Gromada A., Czemu stuży program rodzina 500 plus? Analiza celów polityki publicznej i polityki partyjnej, „Ruch Prawniczy, Ekonomiczny i Socjologiczny” 80, 2018, z. 3.

Gromada A., Rodzina 500+ jako polityka publiczna, Warszawa 2017.

Grzybowski T., Racjonalny prawodawca a orzecznictwo sadowe, https://www.academia. edu/5151143/Racjonalny_prawodawca_a_orzecznictwo_s\%C4\%85dowe (dostęp: 1.02.2020).

GUS, Sytuacja demograficzna Polski do 2018 roku. Tworzenie i rozpad rodzin, Warszawa 2019.

GUS, Zasięg ubóstwa ekonomicznego w Polsce w 2018 r., https://stat.gov.pl/obszary-tematyczne/ warunki-zycia/ubostwo-pomoc-spoleczna/zasieg-ubostwa-ekonomicznego-w-polsce-w-2018-roku, 14,6.html.

Interpreting Statutes, A Comparative Study, red. D.N. MacCormick, R. Summers, Dartmouth 1991.

Jodkowski K., Paradygmat, [w:] Filozofia a nauka. Zarys encyklopedyczny, red. Z. Cackowski, Wrocław 1987.

Kantor-Kozdrowicki P., Racjonalność prawodawcy jako paradygmat nauk prawnych, „Folia Iuridica Universitatis Wratislaviensis" 7, 2018, nr 1.

Kleszcz R., Kryteria racjonalności, „Filozofia Nauki” 4, 1996, nr 2 (14).

Kmita J., Z metodologicznych problemów interpretacji humanistycznej, Warszawa 1971.

Kmita J., Nowak L., O racjonalizującym charakterze badań humanistycznych, „Studia Filozoficzne" 1969 , nr 5.

Koch H-J., Rüssmann H., Jurstische Begründungslehre, München 1982.

Kozak A., Charakterystyka kategorii „racjonalny prawodawca” w sadowym stosowaniu prawa, [w]: Filozoficzno-teoretyczne problemy sądowego stosowania prawa, red. M. Zirk-Sadowski, Łódź 1997.

Król M., Zasada racjonalnej decyzji stosowania prawa, „Studia Prawno-Ekonomiczne” 22, 1979.

Kuhn T.S., Struktura rewolucji naukowych, Warszawa 2009.

Kustra E., Racjonalny ustawodawca analiza teoretycznoprawna, Toruń 1980.

Lang W., Morawski L., Gabrysiak T., Koncepcja „prawodawcy doskonałego” i jej zastosowanie w prawoznawstwie, PiP 1976, z. 1-2.

Lang W., Wróblewski J., Zawadzki S., Teoria państwa i prawa, Warszawa 1979. 
Liwo M.A., Nieracjonalność działań prawodawcy jako jedna z przyczyn niepoprawności prawa - wybrane przyktady z prawa administracyjnego, karnego i prawa pracy, „Przegląd Prawa Publicznego" 2019, nr 6.

Morawski L., Teoria prawodawcy racjonalnego a postmodernizm, „Państwo i Prawo” 2000, z. 11 (657).

Morawski L., Wstęp do prawoznawstwa, Torun 1996.

Morawski L., Zasady wyktadni prawa, Toruń 2006.

Nowak L., Interpretacja prawnicza. Studium z metodologii prawoznawstwa, Warszawa 1973.

Oleś P., Do dyskusji dla czasopisma „Diametros”, „Diametros” 2006, nr 7.

Podsiad A., Stownik terminów i pojęć filozoficznych, Warszawa 2000.

Pszczółkowski L., Racjonalne prawodawstwo, [w:] Wielka encyklopedia prawa, t. 7, red. B. Hołyst, R. Hauser, Warszawa 2014.

Redelbach A., Wronkowska S., Ziembiński Z., Zarys teorii państwa i prawa, Warszawa 1992.

Waismann F., Verifiability, [w:] Logic and Language, Series I, red. A. Flew, Oxford 1953.

Walkowski G.K., Koncepcja idealnego ustawodawcy, [w:] idem, Teoria państwa i prawa, http:// www.teoria-panstwa-i-prawa.com/koncepcja.html (dostęp: 5.02.2020).

Wojciechowski B., Dyskrecjonalność sędziowska, Toruń 2004.

Wojtczak S., Wplyw konceptu „racjonalnego prawodawcy” na polska kulture prawna, [w:] Wielowymiarowość prawa, red. J. Czapska, M. Dudek, M. Stępień, Torun 2014.

Wronkowska S., Prawodawca racjonalny jako wzór dla prawodawcy faktycznego, [w:] Szkice z teorii prawa i szczegółowych nauk prawnych, red. S. Wronkowska, M. Zieliński, Poznań 1989.

Wronkowska S., Problemy racjonalnego tworzenia prawa, Poznań 1982.

Wronkowska S., Zagadnienia racjonalnego tworzenia prawa, „Studia Prawnicze” 1979, z. 2 (60).

Wronkowska S., Ziembiński Z., Zarys teorii prawa, Poznań 1997.

Wróblewski J., Teoria racjonalnego tworzenia prawa, Wrocław 1985.

Zieliński M., Wykładnia prawa. Zasady - reguły - wskazówki, Warszawa 2002.

Ziembiński Z., Metodologiczne zagadnienia prawoznawstwa, Warszawa 1974.

Ziembiński Z., Wstęp do aksjologii dla prawników, Warszawa 1990.

Zirk-Sadowski M., Instytucjonalny i kulturowy wymiar integracji prawnej, [w:] Zmiany społeczne a zmiany w prawie. Aksjologia, konstytucja, integracja europejska, red. L. Leszczyński, Lublin 1999.

Zirk-Sadowski M., Konstrukcja racjonalnego prawodawcy a kompetencja komunikacyjna, [w:] Szkice z teorii prawa i szczegółowych nauk prawnych, red. S. Wronkowska, M. Zieliński, Poznań 1990.

Zirk-Sadowski M., Prawo a uczestniczenie w kulturze, Łódź 1998. 